\title{
(D) Prevalence of IgE-Mediated Food Hypersensitivity to Cereals and Beans Based on Skin Prick Test in Children with Celiac Disease
}

\author{
Ali Jafari ${ }^{1}$, Somayeh Kayvanloo ${ }^{1}$, Nasrin Moazzen ${ }^{1, *}$, Nasrinsadat Motevalli Haghi ${ }^{1}$, Nilufar Sedghi ${ }^{1}$, \\ Maryam Khoshkhui ${ }^{2}$, Hamid Ahanchian ${ }^{1}$
}

1. Clinical Research Development unit of Akbar Hospital, Faculty of Medicine, Mashhad University of medical sciences, Mashhad, Iran .

2. Allergy research center, Mashhad University of medical sciences, Mashhad, Iran

\footnotetext{
* Corresponding Author:

Nasrin Moazzen, MD

Address : Shadid Kaveh Blvd, Akbar children's hospital, Mashhad, Iran

Tel : 00985138713801

Fax : 00985138709201

Email: moazzenn@mums.ac.ir
}

Received : 04 Nov. 2020

Accepted : 07 Jun. 2021

\begin{abstract}
\section{BACKGROUND}

Celiac disease is a non-IgE mediated food allergy, which can cause extensive villus atrophy. Because of increased food allergen absorption, there are elevated $\operatorname{IgA}$ and $\operatorname{IgG}$ antibodies in these patients, so there is a concern about IgE antibody production against wheat and other cereals.
\end{abstract}

\section{METHODS}

In this study, we evaluated IgE-mediated hypersensitivity to wheat, rice, and other cereals in children with celiac disease.

\section{RESULTS}

22 patients $(50 \%)$ had at least one positive skin prick test to food allergens. The most frequent food allergen was peanut $(31.8 \%)$, followed by wheat $(18.2 \%)$, corn $(9.1 \%)$, and rice $(4.5 \%)$. The results revealed no significant correlation between age, sex, and the results of the skin prick test $(p>0.05)$. The correlation between diagnosis time of celiac disease and results of skin prick test was also not significant statistically $(p>0.05)$.

\section{CONCLUSION}

Because of the high prevalence of IgE mediated hypersensitivity to cereals and beans in children with celiac disease, a skin prick test might be considered in these patients, especially in refractory cases.

\section{KEYWORDS:}

Celiac disease, Skin prick test, IgE mediated hypersensitivity, Food allergy

Please cite this paper as:

Jafari A, Kayvanloo S, Moazzen N, Motevalli Haghi N, Sedghi N, Khoshkhui M, Ahanchian H. Prevalence of IgE-Mediated Food Hypersensitivity to Cereals and Beans Based on Skin Prick Test in Children with Celiac Disease. Middle East J Dig Dis 2021; 13: 339-342. doi: 10.34172/mejdd.2021.244

\section{INTRODUCTION}

Celiac disease is a non-IgE mediated food allergy, which is triggered by the ingestion of gluten in genetically susceptible individuals. It is an extensive en- 
teropathy that can cause malabsorption. ${ }^{1-3}$ This lifelong non-IgE mediated food allergy involves one percent of the pediatric and adult population. Clinical manifestations can vary widely. It may begin few months after consumption of gluten-containing foods. ${ }^{4-7}$ Villus atrophy and extensive cellular infiltration are induced by hypersensitivity to gliadin available in gluten. The food allergens in wheat, oat, barley, and rye in genetically susceptible individuals can cause celiac disease. Gluten-specific $\mathrm{T}$ cells are infiltrated in the gastrointestinal (GI) tract, and $80 \%$ of patients produce IgA antibodies against gliadin and tTGase. ${ }^{1,2,4}$ Small intestinal endoscopy with biopsy samples taken from duodenal mucosa and detection of compatible histopathological findings are the gold standard for the diagnosis of celiac disease. Treatment of this chronic autoimmune disorder is a lifelong gluten-free diet. ${ }^{8}$

Patients usually have an increased level of IgG antibodies against several foods, maybe because of increased food allergen absorption from inflamed mucosa in celiac disease. So there are some concerns about the elevation of $\operatorname{IgE}$ antibodies against food allergens. ${ }^{4,9,10}$ Since the diet of these patients is prominently based on cereals, the aim of this study was to evaluate the frequency of IgEmediated food hypersensitivity against cereals through skin prick test in children with celiac disease.

\section{MATERIALS AND METHODS}

This cross-sectional study was performed between April 2018 and January 2019 in the pediatric gastroenterology clinic at Mashhad University of Medical Sciences, Mashhad, Iran. All parents signed a written informed consent prior to participation in the study.

44 patients with celiac disease underwent skin prick tests for some food allergens that most often were used in the patients' diets (wheat, corn, rice, and peanut). Allergen extracts used for skin tests were made by Greer Company (Mail: GREER ${ }^{\circledR}$, PO Box 800 Lenoir, NC 28645). The result was considered positive with wheal reaction $3 \mathrm{~mm}$ greater than the negative control. Data were excluded if the wheal reaction of negative control (saline) was larger than $2 \mathrm{~mm}$ and the wheal reaction of positive control (histamine) was less than $3 \mathrm{~mm}$.

The study was approved by the Ethics Committee of the Medical School at Mashhad University of Medical Sciences (code:IR.MUMS.fm.REC.1396.606)

\section{Statistical analyses}

The results were analyzed using SPSS software version 16 (IBM Inc, Chicago, Il, USA). Statistical analysis was done with the Chi-squared test. The values of the quantitative variables were checked by the Kolmogorov-Smirnov test for normal distribution. The significance level was set at $p<0.05$ in all analyses.

\section{RESULTS}

44 patients with the celiac disease aged between 2 and 17 years (mean age 8.4 years) were recruited, $61.4 \%$ of whom were females, and $38.6 \%$ were males. Seven patients were new cases of celiac disease, and a skin prick test was done before the gluten-free diet. There were also 37 patients with at least 6 months of a gluten-free diet. We compared skin prick test results with food allergens. Chi-square test revealed no significant difference between them (table 1).

22 patients $(50 \%)$ had at least one positive skin prick test to food allergens. The most frequent sensitivity to food allergens was to peanuts $(31.8 \%)$. Other skin sensitivities were to wheat $(18.2 \%)$, corn $(9.1 \%)$, and rice (4.5\%) (tables 2 and 3$)$.

The results revealed no statistically significant differences between age and results of skin prick test $(p>0.05)$.

\section{DISCUSSION}

We investigated the possibility of IgE-mediated food hypersensitivity to wheat, rice, beans, and peanut in 44 patients with celiac disease (mean age 8.4 years) by skin prick test. There was at least one hypersensitivity reaction to the above-mentioned cereals in 22 patients $(50 \%)$, with the most frequent reaction to peanut $(31.8 \%)$ and least to rice $(4.5 \%)$. There was no significant difference between the time of skin prick test (before or after elimination of gluten from diet) and skin reaction to food allergens. All of the 37 patients who were on a gluten-free diet had clinically and serologically remission.

In research that was done by Armentia in Spain, among 57 children with celiac disease, 4 (7\%) children had positive serum IgE to wheat and not to other tested allergens ${ }^{10}$ Just like our patients, their clinical symptoms were not 
Table 1: Statistical analysis between skin prick test result and food allergens

\begin{tabular}{lccccc}
\hline Food allergens & Wheat & Cereal & P-Rice & Corn & Peanut \\
\hline$P$ value (Chi square test) & 0.6 & 0.44 & 0.53 & 0.6 & 0.84 \\
\hline
\end{tabular}

Table 2: Frequency of food hypersensitivity evaluated by skin prick test according to the wheal size

\begin{tabular}{llllll}
\hline Wheal size $(\mathbf{m m})$ & 3 & 4 & 5 & 6 & 7 \\
\hline Peanut & 6 & 3 & 5 & - & - \\
\hline Wheat & 6 & 1 & 1 & - & - \\
\hline Corn & 2 & 1 & 1 & - & - \\
\hline Rice & 1 & 1 & - & - & - \\
\hline
\end{tabular}

Table 3: Frequency of food responsible for food hypersensitivity according to the age

\begin{tabular}{|c|c|c|c|c|}
\hline \multirow{2}{*}{ Food allergens } & \multicolumn{3}{|c|}{ Age groups } & \multirow{2}{*}{$p$ value } \\
\hline & Age groups & Age groups & Age groups & \\
\hline Peanut & 3 & 6 & 5 & 0.35 \\
\hline Wheat & 4 & 3 & 1 & 0.87 \\
\hline Corn & 1 & - & 3 & 0.11 \\
\hline Rice & - & 1 & 1 & 0.10 \\
\hline
\end{tabular}

different from others. In another study, Karhus found that patients with celiac disease had a significantly higher prevalence of IgE sensitization to food mix that is a panel of food allergens (egg, milk, cod, wheat, peanut, and soy) and to wheat. ${ }^{11}$ These results are in accordance with our results that peanut and wheat skin hypersensitivities are among the most prevalent food sensitizations. A possible mechanism behind this finding might be increased food absorption due to damaged epithelial integrity and or immune dysregulation in the intestine. Evaluating common food allergens like cow's milk, egg, seafood and etc. in patients with celiac disease and comparing the results with the results of tests done on normal population might reveal information about abnormal food absorption and induction of $\operatorname{IgE}$ mediated food allergy, especially if patients with uncontrolled celiac disease were selected. On the other hand, some studies conclude that there is high antigen passage from injured intestine, so different allergic diseases are more common in patients with celiac disease. ${ }^{11,12}$ Evaluating of this issue in patient with celiac disease could be useful.

\section{CONCLUSION}

Because of the high prevalence of food allergen hypersensitivity in celiac disease, evaluation of IgE mediated food allergy in such patients might be useful, especially in patients refractory to treatment, in those who develop unexplained symptoms consistent with IgE-mediated food allergy, or in patients with personal or family history of food allergy.

\section{ACKNOWLEDGMENTS}

This work was financially supported by the Digestive Research Center, Kerman University of Medical Sciences, Kerman, Iran (Grant no.: 95/482).

\section{ETHICAL APPROVAL}

There is nothing to be declared. 


\section{CONFLICT OF INTEREST}

The authors declare no conflict of interest related to this work

\section{REFERENCES}

1. TAdkinson NF, Bochner BS, Burks AW, Busse WW, Holgate ST, Lemanske RF et al. Middleton's Allergy: Principles and Practice: Eighth Edition. Elsevier Inc, 2013. 1764 p.

2. Kleinman RE, Goulet OJ, Mieli-Vergani G, Sanderson IR, Sherman PM, Shneider BL, editors. Walker's pediatric gastrointestinal disease: physiology, diagnosis, management. PMPH USA, Ltd; 2018 3.Lebwohl B, Sanders DS, Green PH. Coeliac disease. Lancet 2018 6;391:70-81. doi:: 10.1016/S0140-6736(17)31796-8

3. Lebwohl B, Sanders DS, Green PH. Coeliac disease. Lancet 2018;391:70-81. doi:: 10.1016/S0140-6736(17)31796-8

4. Işikay S, Hizli Ş, Yilmaz K. Prevalence of celiac disease in Turkish children with idiopathic epilepsy. Iran J Pediatr. 2014;24:280.

5. Kliegman, Robert, Bonita Stanton, Joseph W. St. Geme, Nina F. Schor, and Richard E. Behrman. Nelson Textbook of Pediatrics. 20th Edition. Phialdelphia, PA: Elsevier, 2016

6. A Wesley Burks, Stephen T Holgate, Robyn E O'Hehir, Leonard B. Bacharier, David H. Broide, Gurjit K. Hershey, et al. Middleton's Allergy 2-Volume Set, 9th Edition, Elsevier Health Sciences, 2019

7. Khakpour M, Moazzen N, Khakshour A, Norouziasl S, Talebi S, Kianifar H. Growth Pattern Investigation in Cow's Milk Allergic Proctocolitis in Those Who are Under Elimination Diet. Inter J Pediatr 2020;8:12455-60.

8. Kårhus LL, Skaaby T, Madsen AL, Thuesen BH, Schwarz P, Rumessen JJ, et al. The association of celiac disease and allergic disease in a general adult population. United European Gastroenterol J 2019;7:78-89. doi: $10.1177 / 2050640618811485$.

9. Reilly NR, Husby S, Sanders DS, Green PH. Coeliac disease: to biopsy or not? Nat Rev Gastroenterol Hepatol 2018;15:60-66. doi: 10.1038/nrgastro.2017.121.

10. Armentia A, Arranz E, Hernandez N, Garrote A, Panzani R, Blanco A. Allergy after inhalation and ingestion of cereals involve different allergens in allergic and celiac disease. Recent Pat Inflamm Allergy Drug Discov 2008;2:47-57.doi:10.2174/187221308783399234.

11. Ciacci C, Cavallaro R, Iovino P, Sabbatini F, Palumbo A, Amoruso D, et al. Allergy prevalence in adult celiac disease. J Allergy Clin Immunol 2004;113:1199-203. doi: 10.1016/j.jaci.2004.03.012.

12. Kero J, Gissler M, Hemminki E, Isolauri E. Could TH1 and TH2 diseases coexist? Evaluation of asthma incidence in children with coeliac disease, type 1 diabetes, or rheumatoid arthritis: a register study. J Allergy Clin Immunol 2001;108:781-3. doi: 10.1067/mai.2001.119557. 